SPINOZA'S RELIGION 


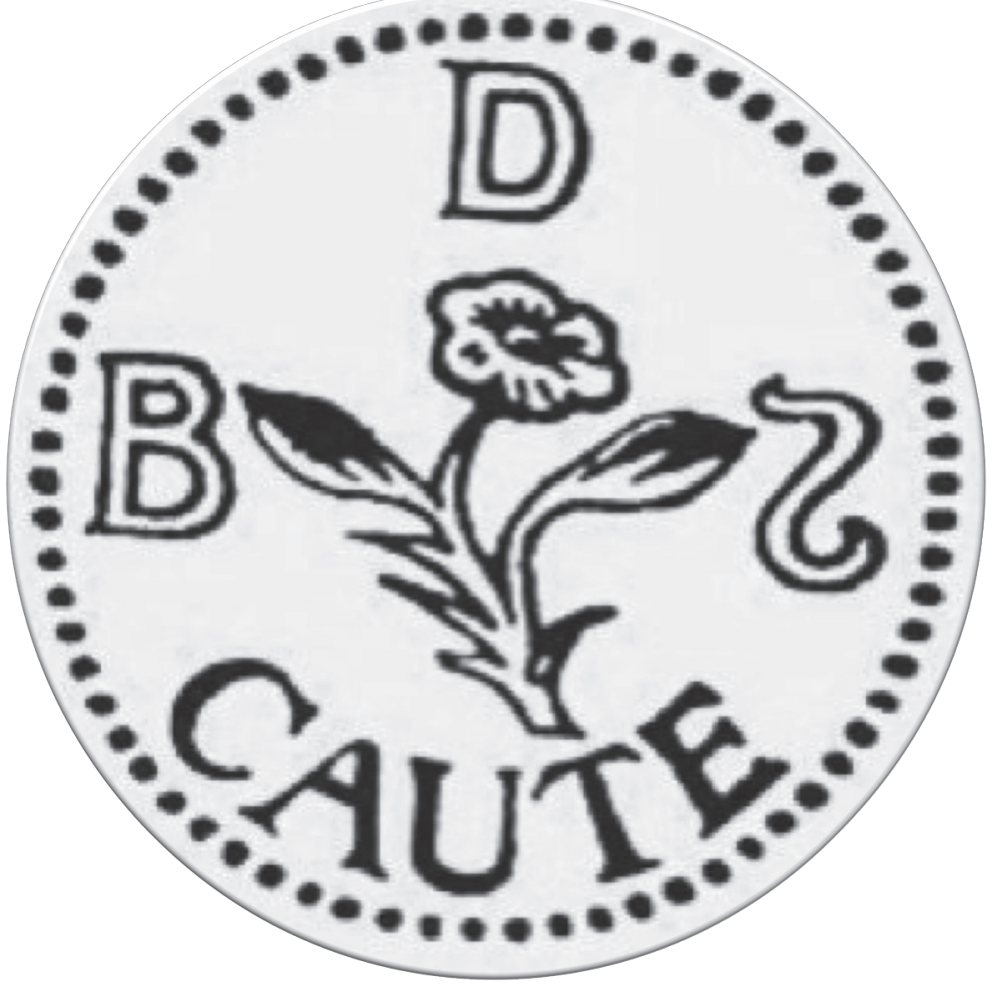




\title{
Spinoza's Religion
}

\section{A NEW READING OF THE ETHICS}

\author{
Banm waseq
}

Clare Carlisle 
Copyright (C) 2021 by Princeton University Press

Princeton University Press is committed to the protection of copyright and the intellectual property our authors entrust to us. Copyright promotes the progress and integrity of knowledge. Thank you for supporting free speech and the global exchange of ideas by purchasing an authorized edition of this book. If you wish to reproduce or distribute any part of it in any form, please obtain permission.

Requests for permission to reproduce material from this work should be sent to permissions@press.princeton.edu

Published by Princeton University Press

41 William Street, Princeton, New Jersey $0854^{\circ}$

6 Oxford Street, Woodstock, Oxfordshire OX20 1TR

press.princeton.edu

All Rights Reserved

Library of Congress Control Number 2021939527

ISBN 978-o-691-17659-8

ISBN (ebook) 978-o-691-22420-6

British Library Cataloging-in-Publication Data is available

Editorial: Ben Tate and Josh Drake

Production Editorial: Debbie Tegarden

Jacket Design: Karl Spurzem

Production: Danielle Amatucci

Publicity: Alyssa Sanford and Amy Stewart

Copyeditor: Francis Eaves

This book has been composed in Classic Miller

Printed on acid-free paper. $\infty$

Printed in the United States of America

10987654321 
To my family: Johnny, Joseph, Katy 

inquietum est cor nostrum, donec requiescat in te 


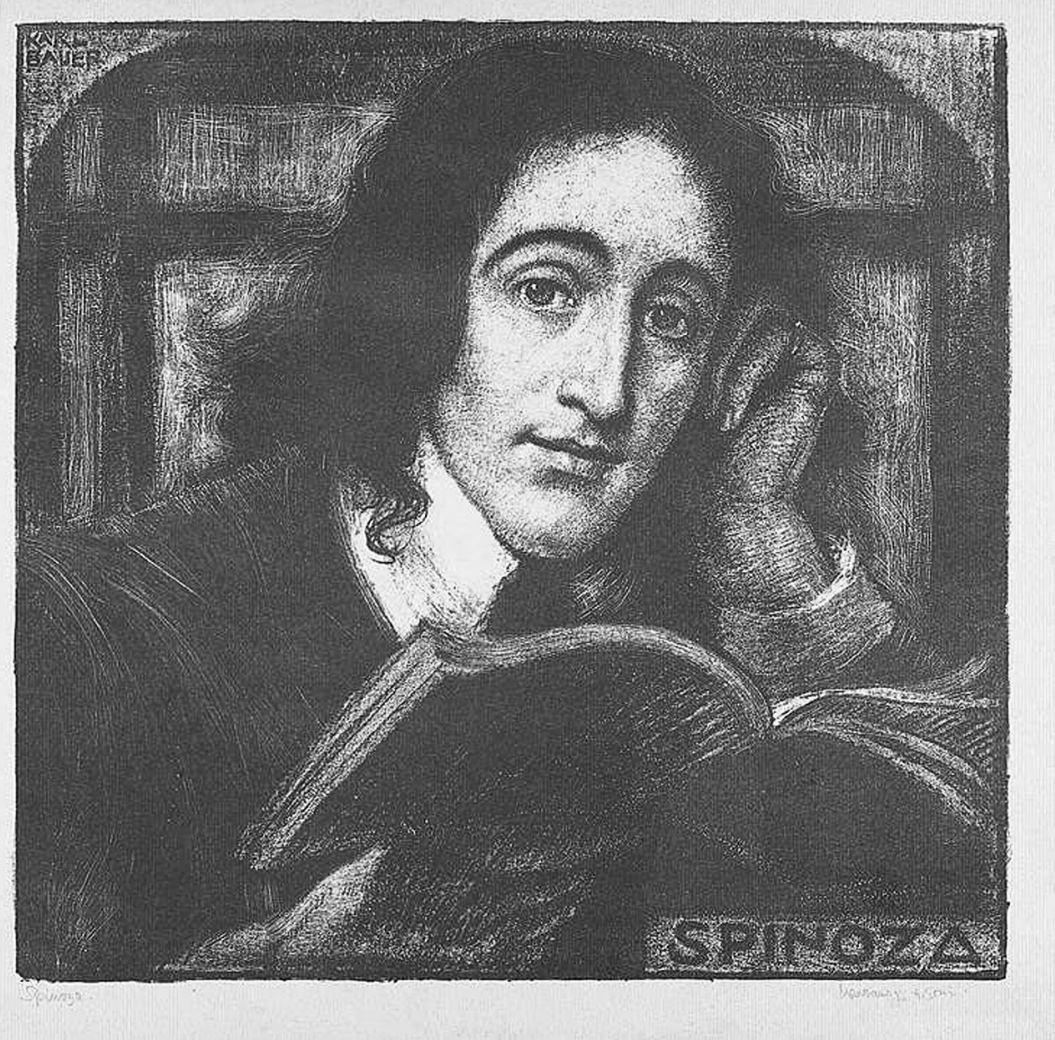

